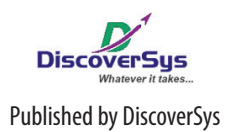

Published by DiscoverSys

\section{Trends in HIV Prevalence, Condom Use and Associated Factors among Female Sex Workers in Denpasar, Bali, Indonesia}

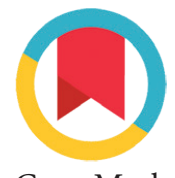

CrossMark

\author{
Dewa Nyoman Wirawan, ${ }^{1,2,3{ }^{*}}$ Emily Rowe, ${ }^{3}$ Made Suarjaya,${ }^{4}$ Luh Putu Sri Armini ${ }^{5}$
}

\title{
ABSTRACT
}

Objectives: The purpose of this paper is to review trends of HIV prevalence, condom use and associated risk factors among the female sex workers (FSW) in Denpasar, Bali.

Methods: To analyze trends of HIV prevalence, surveillance data from 2000-2013 was used. Survey data from 2007 to 2013 was referenced for analysis of condom use trends. Data on associated risk factors was taken from 2012 integrated HIV and behavior survey.

Results and conclusion: HIV prevalence among direct FSW in 2000 was as low as $1.6 \%$ (95\% $\mathrm{Cl}: 0.05-3.15)$ and continued to rise, reaching a prevalence peak of $22.5 \%$ ( $95 \% \mathrm{Cl}$ : $16.4-26.6$ ) in 2010. HIV prevalence began to decline in 2011, 2012 and 2013. Analysis unearthed similar prevalence trends among indirect FSW albeit with a much lower prevalence of $0.25 \%$ in 2001, rising to $7.2 \%$ in 2010 and declining to $2.2 \%$ in 2013. The proportion of direct FSW reporting to always wear condoms in the last working week increased from 38\% in 2007 (95\% Cl: 33.3-42.7) to $65 \%$ in 2013 (95\%Cl: 60.4-69.6). Multivariate analysis with logistic regression indicated that the significant risk factor with HIV prevalence was the specific grouping of FSW, in that low/mid-price are more at risk in comparison to high price with $\mathrm{OR}=4.37(95 \% \mathrm{Cl}$ : 1.42-13.38). Risk factors associated with condom use was also the specific group of FSW, high price reported higher condom use with $\mathrm{OR}=4.04(95 \% \mathrm{Cl}: 2.03-8.04)$ and greater role of sex work site 'pimps' in encouraging their FSW to reject clients refusing to wear condoms with $\mathrm{OR}=2.06$ ( $95 \% \mathrm{Cl}: 1.29-3.30)$. HIV prevalence among indirect and high-price direct FSW was much lower compared to prevalence in low/ mid-price direct FSW. HIV prevalence and condom use among direct FSW population are significantly associated with group price range and the role of 'pimps'.

\section{Tren Prevalensi HIV, Pemakaian Kondom dan Faktor-faktor yang Mempengaruhinya pada Pekerja Seks Wanita di Denpasar, Bali, Indonesia}

\section{ABSTRAK}

Tujuan: Penelitian ini bertujuan untuk melakukan analisis kecenderungan prevalensi HIV dan pemakaian kondom pada pekerja seks wanita (WPS) di Denpasar serta faktor-faktor yang mempengaruhinya.

Metode: Untuk analisis kecenderungan prevalensi HIV dipergunakan data survei HIV sejak tahun 2000 sampai 2013 dan untuk analisis tren pemakaian kondom dipergunakan data survei tahun 2007 sampai dengan tahun 2013. Untuk analisis faktor-faktor yang berhubungan dengan prevalensi HIV dan pemakaian kondom dipergunakan data survei tahun 2012.

Hasil dan simpulan: Prevalensi HIV pada WPS langsung (WPSL) tahun 2000 adalah 1,6\% (95\%Cl: 0,05-3,15) dan terus meningkat sampai mencapai puncaknya pada tahun 2010 dengan prevalensi 22,5\% (95\% Cl: 16,4-26,6), kemudian terlihat mendatar pada tahun 2011, 2012 dan 2013. Kecenderungan yang sama juga dijumpai pada WPS tidak langsung (WPSTL) tetapi dengan prevalensi yang jauh lebih rendah yaitu 0,25\% pada tahun 2001, mencapai puncaknya pada tahun 2010 (7,2\%) dan menurun menjadi 2,2\% pada tahun 2013. Proporsi WPSL yang mengatakan selalu memakai kondom dengan pelanggannya dalam satu minggu terakhir dijumpai meningkat secara bermakna dari 38\% pada tahun 2007 (95\%Cl: 33,3-42,7) menjadi $65 \%$ pada tahun 2013 (95\%Cl: 60,4-69,6). Analisis multivariat dengan regresi logistik menunjukkan bahwa faktor yang secara bermakna berhubungan dengan prevalensi HIV adalah kelompok WPSL dengan $O R=4,37$ (95\% Cl: 1,42-13,38), dan faktor yang berkaitan dengan pemakaian kondom adalah kelompok WPSL dengan OR=4,04 (95\% Cl: 2,03-8,04) dan karena diharuskan oleh "bos" untuk menolak tamunya yang tidak memakai kondom dengan $\mathrm{OR}=2,06$ (95\% Cl: 1,29-3,30). Prevalensi HIV pada WPSTL dan WPSL kelompok "high price" jauh lebih rendah dibandingkan WPSL kelompok "low/mid price". Prevalensi HIV dan pemakaian kondom pada semua WPSL secara bermakna berkaitan dengan kelompok WPS dan peranan dari “bos” mereka. 
Kata kunci: prevalensi HIV, pemakaian kondom, pekerja seks perempuan, Bali, Indonesia

Kutip artikel ini: Wirawan, D.N., Rowe, E., Suarjaya, M., Armini, L.P.S. 2014. Tren Prevalensi HIV, Pemakaian Kondom dan Faktor-faktor yang Mempengaruhinya pada Pekerja Seks Wanita di Denpasar, Bali, Indonesia. Public Health and Preventive Medicine Archive 2(1): 2-11. D0l:10.15562/ phpma.v2i1.115

\section{INTRODUCTION}

The corresponding author first conducted behavioral studies with female sex worker (FSW) populations in 1989. ${ }^{1}$ The Kerti Praja Foundation (KPF) began carrying out outreach education, condom distribution and implementation research among both indirect and direct FSW communities in $1994 .^{2}$ Direct FSW are those whose sole income is obtained through sex work, whereas indirect FSW conduct sex work as a supplementary income activity in sites such as massage parlors, cafes, karaoke clubs, bars, beauty salons amongst others.

Since $1996 \mathrm{KPF}$ has been providing clinical services (sexually transmitted infections screening and treatment) for the FSW population in Denpasar and the surrounding areas. In 2000, KPF began offering voluntary HIV counseling and testing (VCT) services for FSW and other at risk communities such as injecting drug users (IDUs), men who have sex with men (MSM), transgender, high risk behavior men and the general public. In 2002, in response to the increasing demand for HIV-related services, KPF began providing antiretroviral therapy (ART) facilities as well as care, support and treatment (CST) for people living with HIV/AIDS (PLWHA). ART services were implemented on a national level by the Indonesian Government in 2005.

In Indonesia, sentinel HIV survey with FSW has been conducted since 2004 yet only carried out by a number of cities, including Denpasar, Bali, however, only with indirect FSW (massage parlors). As a result, it is difficult to ascertain annual HIV prevalence provincially and nationally, and among direct FSW in Bali. Aside from HIV prevalence trends among FSW, in order to gain further insight it is important to examine condom use trends, as well as associated behavioral variables. The Indonesian Ministry of Health $(\mathrm{MOH})$ conducted biological and behavioral surveillance (IBBS) in a number of cities however only on two occasions, in 2007 and 2011. ${ }^{5}$ Concerning trends in Denpasar, HIV survey data on both direct and indirect FSW from 2000 to 2013 is available from KPF and Bali Provincial Health Department (BPHD). In Bali, in addition to the aforementioned $\mathrm{MOH}$ IBBS, integrated biological and behavioral survey have also been conducted by KPF and BPHD. This paper seeks to describe HIV prevalence trends among direct and indirect FSW since 2000-2013 and examine associated factors, including condom use, socio-demographic and intervention variables.

\section{METHODS}

KPF conducted sentinel HIV survey among direct FSW from 2000 to 2013, excluding the years 2002 and 2003 (Table 1). Sentinel survey from 2004 to 2013 was conducted in collaboration with the BPHD. The BPHD provided logistical support for extracting blood samples and HIV testing, and KPF was responsible for population listing for random sampling. Blood samples were taken whilst in the field or at the KPF clinic, then sent to BPHD for laboratory testing.

In Denpasar, there is an estimated population of 1500 direct FSW, however, only between 10001200 were successfully registered for sampling. For every sentinel survey, a random sample of 250 or 400 FSW was taken, excluding the year of 2004 wherein only 181 samples were taken. Sentinel HIV survey of indirect FSW was carried out by the Denpasar Health Department in massage parlors around Denpasar City. HIV testing was done with all encountered women working at these massage parlors during the survey (without sampling) with between 200 to 250 FSW in each survey. HIV testing in 2000 to 2008 was done using enzymelinked immunosorbent assay (ELISA) and since 2009 onwards with three rapid tests.

In 2007, 2009, 2012 and 2013 behavioral interviews were integrated with the HIV testing among 400 direct FSW using the same questionnaire, which had been tested beforehand. Interviews were facilitated by KPF outreach staff, however in order to reduce possibility of bias, it was arranged that staff interviewed FSW that were unknown to them. Behavioral surveys of 2012 were funded by KPF, whereas surveys of 2007 , 2009 and 2013 were supported by the Indonesian National AIDS Commission. Data on condom use trends discussed in this paper were findings from the behavioral studies of 2007, 2009 and 2013; HIV survey and behavior surveys from 2012 were used for examining the association between condom use and socio-demographic and intervention variables and was analyzed using Stata SE 12.1. These annual HIV and behavior surveys were approved by the Kerti Praja Foundation Institutional Review Board. 


\section{RESULTS}

\section{Trends in HIV prevalence}

Table-1 presents the HIV prevalence trends from 2000 up to 2013. In the year 2000 prevalence was as low as $1.6 \%$ (95\%CI: 0.05-3.15) and reached prevalence peak in 2010 with a prevalence as high as $22.5 \%$ (95\%CI: 16.4-26.6). Prevalence declined to $19.5 \%$ (95\%CI: 15.6-23.4) in 2011, and continued to decline to $18.2 \%$ (95\%CI: $14.4-22.0$ ) in 2012, yet increased slightly in 2013 to $19.8 \%$ (95\%CI: 16.0-23.6). Trends among indirect FSW were similar to trends among direct FSW, however with a significantly lower prevalence of $0.25 \%$ in 2001 , reaching a prevalence peak of $7.2 \%$ in 2010 , then decline to $5.5 \%$ in 2012 and $2.2 \%$ in 2013 (Figure 1).

\section{Characteristics of direct FSW and HIV prevalence}

Data from the 2012 survey, indicated that HIV prevalence among direct FSW varied depending upon population characteristics and specific FSW group (Table 2). Table-3 shows the characteristics of low/mid and high price direct FSW. Low price FSW refers to street based FSW, freelance or

Table 1 Prevalence of HIV among direct FSW in Denpasar, 20102013

\begin{tabular}{llccc}
\hline Year & Researchers & Sample & Prevalence (\%) & $\mathbf{9 5 \% ~ C l ~}$ \\
\hline 2000 & KPF & 250 & 1.6 & $0.05-3.15$ \\
2001 & KPF & 250 & 7.0 & $3.90-10.1$ \\
2004 & KPF and BPHD ${ }^{*}$ & 181 & 8.8 & $4.70-12.9$ \\
2005 & KPF and BPHD & 400 & 8.5 & $5.80-11.2$ \\
2006 & KPF and BPHD & 250 & 12.4 & $8.40-16.4$ \\
2007 & KPF and BPHD & 250 & 14.5 & $10.2-18.8$ \\
2008 & KPF and BPHD & 400 & 15.2 & $11.7-18.7$ \\
2009 & KPF and BPHD & 400 & 20.5 & $16.5-24.5$ \\
2010 & KPF and BPHD & 400 & 22.5 & $16.4-26.6$ \\
2011 & KPF and BPHD & 400 & 19.5 & $15.6-23.4$ \\
2012 & KPF and BPHD & 400 & 18.2 & $14.4-22.0$ \\
2013 & KPF and BPHD & 400 & 19.8 & $16.0-23.6$ \\
\hline
\end{tabular}

*) KPF: Kerti Praja Foundation, BPHD: Bali Province Health Department

Table 2 Prevalence of HIV among direct FSW by type and price, Denpasar 2012

\begin{tabular}{lcccc}
\hline $\begin{array}{l}\text { Group of } \\
\text { FSW }\end{array}$ & $\begin{array}{c}\text { Number of direct FSW } \\
\text { during the survey }\end{array}$ & $\begin{array}{c}\text { Number of } \\
\text { sample }\end{array}$ & HIV+ & \% HIV++ \\
\hline Low price & 37 & 15 & 6 & 40.0 \\
Mid price & 726 & 300 & 63 & 21.0 \\
High price & 219 & 85 & 4 & 4.7 \\
Total & 982 & 400 & 73 & 18.3 \\
\hline
\end{tabular}

those working without 'pimp' supervision, and these FSW are predominately older and attained lower schooling/education levels. HIV prevalence among this group was $40 \%$ in 2012 (Table-2). Mid-price FSW population greatly outnumbers the other groupings, with the majority living outside work site, and conducting sex transactions at the residence of the 'pimp'. HIV prevalence within this group was $21 \%$. In high price FSW populations, sex workers are generally younger $(\mathrm{p}<0.001)$, better educated $(\mathrm{p}<0.001)$, have not been working for a lengthy period of time $(\mathrm{p}=0.001)$, and serve more clients $(\mathrm{p}<0.001)$. The majority of high price FSW live in lodgings provided by their 'pimp'. HIV prevalence among this group was $4.7 \%$.

\section{Association between HIV prevalence with socio-demographic and behavioral variables}

Table 4 illustrates differences in HIV prevalence among direct FSW with socio-demographic and behavioral variables.

These are age, education, length of time working as a FSW, number of clients in last week, frequency of condom use in last week, and condom use with regular intimate partner.

Table 4 illustrates that HIV prevalence among FSW under the age of 25 was $10.8 \%$, whereas in the age group of 25-29, 30-34, and 35-52 prevalence was $22.4 \%, 21.1 \%$, and $20.7 \%(\mathrm{p}=0.092)$ respectively. If disaggregated into two age groups, HIV prevalence in under 25 FSW was $10.8 \%$ and with over 25 years old FSW prevalence was $21.4 \%(\mathrm{p}=0.007)$. HIV prevalence also differs greatly with regards to education levels $(\mathrm{p}=0.004)$, length of time as FSW $(\mathrm{p}<0.001)$ and number of clients in last week $(\mathrm{p}=0.044)$. HIV prevalence does not differ significantly regarding condom use with client in last week $(\mathrm{p}=0.131)$ and with condom use and regular intimate partners $(\mathrm{p}=0.897)$. This difference is associated with specific FSW population, in that HIV prevalence among high price FSW is low at 4.7\% (Table-2), whereas this group differs greatly with age, education, length of time working as FSW and number of clients with low/mid-price FSW (Table-3).

Multivariate analysis using logistic regression indicates that significant factors were the association between HIV prevalence and specific group of FSW with OR=4.37 (95\%CI: 1.42-13.38) and length of time working as a FSW with OR=0.55 (95\%CI: 0.42$0.74)$. FSW low/mid-price have a risk potential 4.37 times greater than high price FSW and those FSW working for a shorter period of time have a lower risk potential of 0.55 if compared to those working for a lengthier period of time (Table-5). 
Table 3 Socio-demographic characteristics of low/mid and high price direct FSW, Denpasar 2012

\begin{tabular}{|c|c|c|c|}
\hline Characteristics & Low/mid price & High price & p value \\
\hline Age (years) & & & $<0.001$ \\
\hline $18-24$ & $73(23.2)$ & $47(55.3)$ & \\
\hline $25-29$ & $74(23.5)$ & $24(28.2)$ & \\
\hline $30-34$ & $82(26.0)$ & $13(15.3)$ & \\
\hline $35-52$ & $86(27.3)$ & $1(1.2)$ & \\
\hline Education level & & & $<0.001$ \\
\hline Never schooled & $36(11.4)$ & $2(2.4)$ & \\
\hline Elementary & $144(45.7)$ & $13(15.3)$ & \\
\hline Junior high school & $98(31.1)$ & $48(56.5)$ & \\
\hline Senior high school & $37(11.7)$ & $22(25.9)$ & \\
\hline Length of time as FSW (months) & & & 0.001 \\
\hline$<12$ & $87(27.6)$ & $40(47.1)$ & \\
\hline $12-23$ & $7122.5)$ & $11(12.9)$ & \\
\hline $24-48$ & $103(32.7)$ & $28(32.9)$ & \\
\hline $49-180$ & $54(17.1)$ & $6(7.1)$ & \\
\hline Number of clients in the past week & & & $<0.001$ \\
\hline $1-7$ & $130(41.3)$ & $7(8.2)$ & \\
\hline $8-14$ & $85(27.0)$ & $22(25.9)$ & \\
\hline $15-24$ & $63(20.0)$ & $22(25.9)$ & \\
\hline $25-99$ & $37(11.7)$ & $34(40.0)$ & \\
\hline Condom use with clients in the past week & & & $<0.001$ \\
\hline Never/rarely & $28(8.9)$ & $0(0.0)$ & \\
\hline Often & $117(37.1)$ & $15(17.6)$ & \\
\hline Always & $170(54.0)$ & $70(82.4)$ & \\
\hline Condom use with intimate sexual partner & & & 0.725 \\
\hline Never & $141(65.3)$ & $34(61.8)$ & \\
\hline Sometimes & $45(20.8)$ & $11(20.0)$ & \\
\hline Often/always & $30(13.9)$ & $10(18.2)$ & \\
\hline No intimate sexual partner & 99 & 30 & \\
\hline $\begin{array}{l}\text { Frequency receiving education from } \\
\text { outreach staff }\end{array}$ & & & 0.182 \\
\hline$<4$ & $208(66.0)$ & $51(60.0)$ & \\
\hline$>4$ & $107(34.0)$ & $34(40.0)$ & \\
\hline $\begin{array}{l}\text { Condom demonstration with dildo by } \\
\text { outreach staff }\end{array}$ & & & 0.064 \\
\hline Yes & $205(65.1)$ & $47(55.3)$ & \\
\hline No & $110(34.9)$ & $38(44.7)$ & \\
\hline $\begin{array}{l}\text { Frequency of information about condom } \\
\text { from 'pimp' }\end{array}$ & & & 0.108 \\
\hline$<4$ & $221(70.2)$ & $53(62.4)$ & \\
\hline$>4$ & $94(29.8)$ & $32(37.6)$ & \\
\hline
\end{tabular}


Table 3 Continue

\begin{tabular}{|c|c|c|c|}
\hline Characteristics & Low/mid price & High price & p value*) \\
\hline $\begin{array}{l}\text { Frequency of reminders from 'pimps' to } \\
\text { FSW about rejection of clients refusing } \\
\text { condom use }\end{array}$ & & & 0.007 \\
\hline Never & $145(46.0)$ & $26(30.6)$ & \\
\hline$>1$ & $170(54.0)$ & $59(69.4)$ & \\
\hline HIV infection risk perception & & & 0.059 \\
\hline No/low/medium risk & $85(27.0)$ & $31(36.5)$ & \\
\hline High risk & $230(73.0)$ & $54(63.5)$ & \\
\hline Total & $315(78,8)$ & $85(21,2)$ & \\
\hline
\end{tabular}

${ }^{*} \mathrm{X}^{2}$ test

Table 4 Association of HIV prevalence with socio-demographic and behavioral variables among direct FSW, Denpasar, 2012

\begin{tabular}{|c|c|c|c|c|}
\hline Characteristics & $\mathbf{n}$ & HIV+ & HIV prevalence (\%) & p value ${ }^{*}$ \\
\hline Age (years) & & & & 0.092 \\
\hline $18-24$ & 120 & 13 & 10.8 & \\
\hline $25-29$ & 98 & 22 & 22.4 & \\
\hline $30-34$ & 95 & 20 & 21.1 & \\
\hline $35-52$ & 87 & 18 & 20.7 & \\
\hline Education & & & & 0.004 \\
\hline Never schooled & 38 & 13 & 34.2 & \\
\hline Elementary & 157 & 35 & 22.3 & \\
\hline Junior high school & 146 & 18 & 12.3 & \\
\hline Senior high school & 59 & 7 & 11.9 & \\
\hline Length of time as FSW (months) & & & & $<0.001$ \\
\hline$<12$ & 127 & 9 & 7.1 & \\
\hline $12-23$ & 82 & 10 & 12.2 & \\
\hline $24-48$ & 131 & 36 & 27.5 & \\
\hline $49-180$ & 60 & 18 & 30.0 & \\
\hline Number of clients in the past week & & & & 0.044 \\
\hline $1-7$ & 137 & 34 & 24.8 & \\
\hline $8-14$ & 107 & 16 & 15.0 & \\
\hline $15-24$ & 85 & 16 & 18.8 & \\
\hline $25-99$ & 71 & 7 & 9.9 & \\
\hline Condom use with clients in the past week & & & & 0.131 \\
\hline Never/rarely & 28 & 8 & 28.6 & \\
\hline Often & 132 & 28 & 21.2 & \\
\hline Always & 240 & 37 & 15.4 & \\
\hline Condom use with intimate sexual partner & & & & 0.897 \\
\hline Never & 175 & 29 & 16.6 & \\
\hline Sometimes & 56 & 8 & 14.3 & \\
\hline Often/always & 40 & 7 & 17.5 & \\
\hline No intimate sexual partner & 129 & - & - & \\
\hline Total & 400 & 73 & 18.3 & \\
\hline
\end{tabular}

${ }^{*} \mathrm{X}^{2}$ test 
Table 5 Adjusted odd ratio risk factors for HIV prevalence among direct FSW in Denpasar, 2012

\begin{tabular}{lccc}
\hline Characteristics & OR & $\mathbf{9 5 \% ~ C l}$ & P value \\
\hline Group of direct FSW & 4.37 & $1.42-13.38$ & 0.01 \\
Length of time working as FSW & 0.55 & $0.42-0.74$ & $<0.001$ \\
Age & 1.00 & $0.67-1.51$ & 0.974 \\
Education level & 1.31 & $0.92-1.86$ & 0.131 \\
Condom use & 1.13 & $0.74-1.71$ & 0.570 \\
Number of clients in the last week & 1.10 & $0.82-1.44$ & 0.561
\end{tabular}

Table 6 Association of condom use with clients in the past week with socio-demographic and intervention variables among direct FSW, Denpasar, 2012

\begin{tabular}{|c|c|c|c|}
\hline \multirow{2}{*}{$\begin{array}{l}\text { Characteristics } \\
\text { Age (years) }\end{array}$} & \multicolumn{2}{|c|}{ Condom use in the past week } & \multirow{2}{*}{$\frac{\text { p value }^{*}}{0.037}$} \\
\hline & Always & Not always & \\
\hline $18-24$ & $80(66.7)$ & $40(33.3)$ & \\
\hline $25-29$ & $65(66.3)$ & $33(33.7)$ & \\
\hline $30-34$ & $50(52.6)$ & $45(47.4)$ & \\
\hline $35-52$ & $45(51.7)$ & $42(48.3)$ & \\
\hline Education & & & 0.012 \\
\hline Never & $21(55.3)$ & $17(44.7)$ & \\
\hline Elementary & $80(51.0)$ & $77(49.0)$ & \\
\hline Junior high school & $100(68.5)$ & $46(31.5)$ & \\
\hline Senior high school & $39(66.1)$ & $20(33.9)$ & \\
\hline Length of time working as FSW (months) & & & 0.068 \\
\hline$<12$ & $86(67.7)$ & $41(32.3)$ & \\
\hline $12-23$ & $52(63.4)$ & $30(36.6)$ & \\
\hline $24-48$ & $71(54.2)$ & $60(45.8)$ & \\
\hline $49-180$ & $31(51.7)$ & $29(48.3)$ & \\
\hline Number of clients in the past week & & & 0.343 \\
\hline $1-7$ & $90(65.7)$ & $47(34.3)$ & \\
\hline $8-14$ & $60(56.1)$ & 47 (43.9) & \\
\hline $15-24$ & $47(55.3)$ & $38(44.7)$ & \\
\hline $25-99$ & $43(60.6)$ & $28(39.4)$ & \\
\hline $\begin{array}{l}\text { Frequency of information dissemination by } \\
\text { outreach staff }\end{array}$ & & & 0.425 \\
\hline$<4$ & $154(59.5)$ & $105(40.5)$ & \\
\hline$>4$ & $86(61.0)$ & $55(39.0)$ & \\
\hline $\begin{array}{l}\text { Condom demonstration with dildo by outreach } \\
\text { staff }\end{array}$ & & & 0.474 \\
\hline Yes & $152(60.3)$ & $100(39.7)$ & \\
\hline No & $88(59.5)$ & $60(40.5)$ & \\
\hline $\begin{array}{l}\text { Frequency of Information about condom use } \\
\text { from 'pimps' }\end{array}$ & & & 0.014 \\
\hline$<4$ & $154(56.2)$ & $120(43.8)$ & \\
\hline$>4$ & $86(68.3)$ & $40(31.7)$ & \\
\hline
\end{tabular}


Table 6 Continue

\begin{tabular}{|c|c|c|c|}
\hline Characteristics & \multicolumn{2}{|c|}{ Condom use in the past week } & p value ${ }^{*}$ \\
\hline $\begin{array}{l}\text { Frequency of reminders from 'pimps' to reject } \\
\text { clients refusing to wear condoms }\end{array}$ & & & $<0.001$ \\
\hline Never & $83(48.5)$ & $88(51.5)$ & \\
\hline$>1$ & $157(68.6)$ & $72(31.4)$ & \\
\hline HIV infection risk perception & & & 0.190 \\
\hline No/low/medium risk & $74(63.8)$ & $42(36.2)$ & \\
\hline High risk & $166(58.9)$ & $118(41.5)$ & \\
\hline Total & $240(60.0)$ & $160(40.0)$ & \\
\hline
\end{tabular}

${ }^{*} \mathrm{X}^{2}$ test

Table 7 Adjusted odd ratio risk factors of always and not always using condoms among direct FSW in Denpasar, 2012

\begin{tabular}{lllc}
\hline Characteristics & OR & $\mathbf{9 5 \%} \mathbf{~ I ~}$ & p value \\
\hline Group of direct FSW & 4.04 & $2.03-8.04$ & 0.001 \\
Reminders from 'pimps' to reject clients refusing to wear & 2.06 & $1.29-3.30$ & 0.003 \\
condoms & & & 0.001 \\
Number of clients in the past week & 0.68 & $0.54-0.85$ & 0.883 \\
Age & 0.98 & $0.80-1.22$ & 0.337 \\
Education & 1.14 & $0.87-1.50$ & 0.149 \\
Length of time working as FSW & 0.85 & $0.68-1.06$ & 0.848 \\
Frequency of information dissemination by outreach staff & 1.05 & $0.63-1.74$ & 0.763 \\
Condom demonstration with dildo by outreach staff & 1.08 & $0.67-1.73$ & 0.367 \\
Frequency of Information about condom use from 'pimp' & 1.28 & $0.75-2.20$ & $0.44-1.23$ \\
HIV infection risk perception & 0.74 & & 0.241 \\
\hline
\end{tabular}

\section{Trends of condom use}

Figure 2 illustrates condom use trends as reported by FSW during interviews. The number of direct FSW respondents was 400 for each survey. Two questions were proposed to respondents: were condoms used during last sex transaction and did all clients use condoms in the week leading up to the interview. In the 2007 survey, questions regarding last sex transaction and condom use were not asked. Condom use during last sex transaction trends indicate a significant increase from $66 \%$ (95\%CI: $61.4-70.6$ ) in 2009 , to $75 \%$ in 2013 (95\%CI: 70.8-79.2), and the proportion of respondents stating that all clients used condoms in the last week also greatly increased from $38 \%$ in 2007 (95\%CI: 33.3-42.7) to $65 \%$ in 2013 (95\%CI: 60.4-69.6).

\section{Association between condom use with clients in the past week with socio- demographic and intervention variables}

Table 6 is a bivariate analysis to see the association between condom use with socio-demographic and intervention variables. Condom use data has been segregated into two categories, that is, 'always use' and 'rarely use' condoms with clients in the week leading up to the interview. The proportion of direct sex workers that always use condoms varies significantly with regards to age $(\mathrm{p}=0.037)$, education levels $(\mathrm{p}=0.012)$, frequency of condom promotion by 'pimps' $(\mathrm{p}=0.014)$ and frequency of reminders by 'pimps' for FSW to reject clients refusing condom use $(\mathrm{p}<0.001)$. This is potentially related to the difference between frequency in condom use among high and low/mid-price. Table 3 illustrates that condom use is significantly higher among high price FSW (82.4\%) compared to just 54\% among low/mid-price FSW ( $<<0.001)$.

Multivariate analysis indicates that the variable significantly associated with condom use (low/mid versus high price) with $\mathrm{OR}=4.04$ (95\%CI: 2.03 8.04) and the involvement of 'pimps' in promoting condom use and reminding their FSW employees to reject clients refusing to wear condoms with $\mathrm{OR}=2.06$ (95\%CI: 1.29-3.30). 


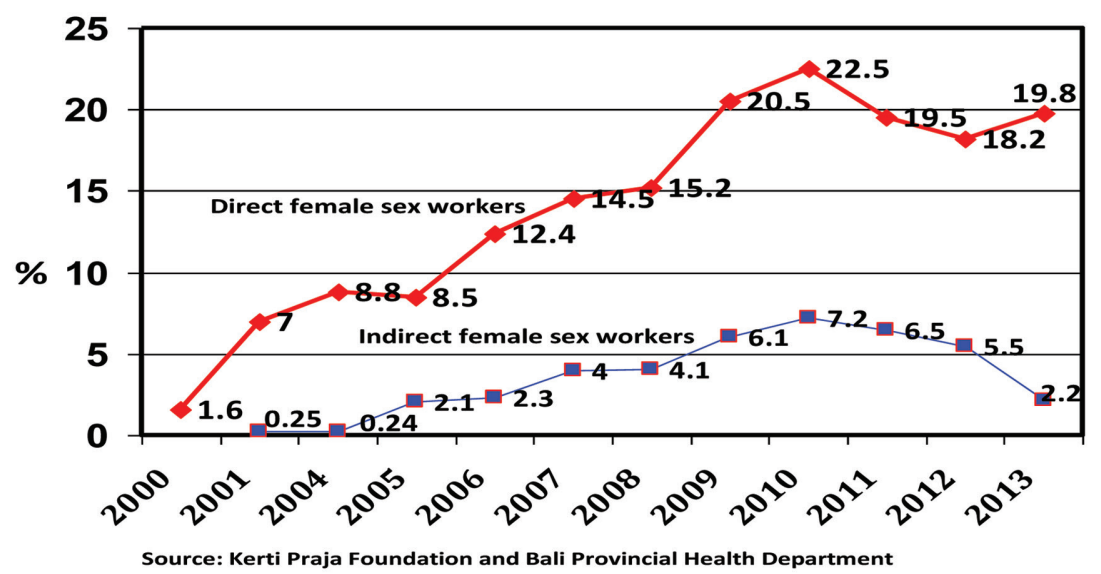

Figure 1 HIV prevalence among female sex workers Denpasar, Bali $(2000-2013)$

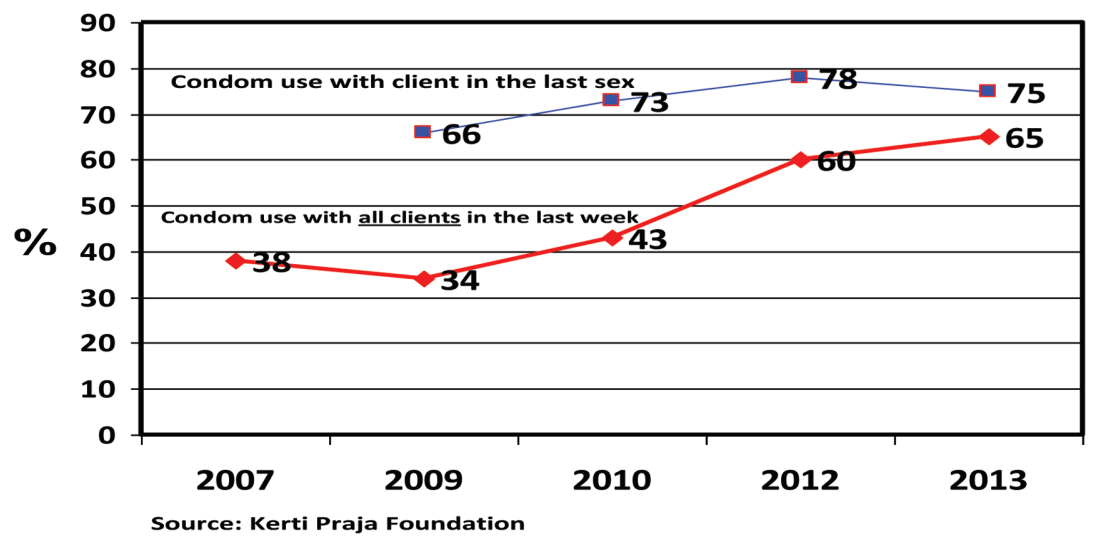

Figure 2 Condom use among direct female sex workers, Denpasar, Bali $(2007-2013)$

\section{DISCUSSION}

IBBS results from 2011 indicate that HIV prevalence among direct FSW in Denpasar was $16 \%{ }^{5}$ which is lower than the $19.5 \%$ discovered through survey by KPF. This difference is possibly owing to the fact that IBBS was not followed through with blood sampling and testing with low price FSW communities in Denpasar. When compared to other cities in Indonesia, HIV prevalence was higher in Denpasar than cities in Java and Sumatera, where prevalence ranges from $3.6 \%$ to $11.6 \%$, excluding the district of Batang in Central Java province (20.7\%). However, prevalence was lower than Jayawijaya area in Indonesian Papua, that has a prevalence of $25.0 \%{ }^{5}$

BED capture enzyme immunoassay of the 2007 IBBS HIV prevalence data produced an estimate of HIV incidence among FSW in Denpasar of 8.5 per 100 person (95\%CI: $2.4-14.5){ }^{6}$ Estimates of HIV incidence among FSW in other cities was lower: Batam (6.1; 95\%CI: 2.5-9.6), Jakarta (3.5; 95\%CI: $0.8-6.2)$, Surabaya (1.9; 95\%CI: 0.0-3.8), Jayapura (1.8; 95\%CI: 0.0-3.9), and Bandung (1.7; 95\%CI: $0.0-3.5){ }^{6}$
These high infection rates are possibly associated with the low circumcision of males in Hindu Bali and in Christian Jayawijaya, as opposed to the different religio-cultural situation of Sumatera and Java wherein the population is predominately Moslem, and therefore circumcised. Three randomized controlled intervention trials in Kenya and Uganda revealed that male circumcision can reduce the risk of HIV transmission. ${ }^{7-9}$ A systematic review and meta-analysis of 28 published studies found that circumcised men are two to three fold less likely to become infected by HIV than uncircumcised men. ${ }^{10}$ An observational study in Uganda also found that male circumcision may also protect against maleto-female sexual transmission of HIV. ${ }^{10,11}$

By reviewing HIV prevalence trends among direct FSW in Denpasar, it is evident that the highest prevalence rate was $22.5 \%$ in 2010 , then the rate declined in 2011, 2012, and 2013 to between $18.2-19.8 \%$. Similar trends were also evident in the proportion of direct FSW that underwent VCT and tested HIV+ in Denpasar which peaked in 2009, then started to decline in 2010, 2011, 2012 and 2013. The number of direct FSW that underwent VCT and tested HIV+ are as follows: 2003 (60 undergoing VCT, 3.3\% HIV+), 2004 (95; 4.2\%), 2005 (162; 3.7\%), 2006 (147; 8.2\%), 2007 (995; 7.3\%), 2008 (868; 8.6\%), 2009 (907; 9.2\%), 2010 (863; 6.3\%), 2011 (726; 5.5\%), 2012 (812; 5.8\%), 2013 (782; 4.7\%).

A decline in HIV prevalence after 2010 is potentially related to a number of factors. Firstly, it is possible that the number of AIDS related deaths among direct FSW was greater than the number of new infections. Within KPF clinical records, it is evident that a number of HIV+ FSW have passed away due to AIDS related disease, but that also a large number of the population is living longer due to ARV treatment. Secondly, there is a possibility that during surveillance a proportion of HIV+ FSW were temporarily outside of Bali. However, according to KPF staff listing prior to survey implementation, according to 'pimps' and their FSW employees, few FSWs were outside of Denpasar at the time. Finally, it is possible that the HIV infection rate was indeed beginning to decline due to an increase in condom use and in ARV treatment. In order to further explore these, it would be beneficial to conduct a prospective study with a cohort of FSW, measuring new infection trends (HIV incidence) as well as research into the impact of ARV treatment upon viral load through viral load testing.

HIV prevalence differs greatly between high price FSW (4.7\%), mid-price FSW (21\%) and low price FSW (40\%). Prevalence was far higher among 
low/mid-price as this population is generally much older, and they have worked as FSW for a longer period of time, thereby increasing their possibility of exposure to HIV. Among this group, education levels are lower, as are the education levels of their male clients, these low schooling levels possibly impacting upon knowledge of condoms and tendency for condom use. Lower price FSW work in general in street-based sex work, so are harder to reach and educate through outreach activities. FSW who have been working for a shorter length of time and are younger, predominately have lower HIV prevalence even though the numbers of clients they serve are much higher. Aside from a shorter possible HIV exposure timeframe, the majority of this segment of the population state that they always wear condoms during transaction ( $54 \%$ versus $82.4 \%$ ).

There is a reported increase in condom use for the last working week from $38 \%$ in 2007 to $65 \%$ in 2013. As illustrated above, the 2012 survey discovered that only $54 \%$ of low/mid-price FSW reported always wearing condoms, whereas among high price FSW this was much higher, at $82.4 \%$. This finding is supported by sales reports from condom distributors in Denpasar that report an increase in sales from $3,473,856$ pieces in 2009 to $3,704,976$ (in 2010), 3,796,848 pieces (in 2011), $4,277,952$ pieces (in 2012) and 5,014,512 pieces (in 2013). To summarize, condoms sales have risen as much as $44 \%$ in 2013 compared to condoms sales in 2009 .

Factor behind the rise in condom sales is possibly to prevent STI and HIV transmission as the use of condoms as a family planning measure has declined from $2.9 \%$ in 2007 to $2.7 \%$ in $2012 .{ }^{12,13}$ Data on STIs trends also indicate a decline: IBBS from 2011 reported that only $1.6 \%$ of direct FSW in Denpasar presented with active syphilis (RPR $>=1: 8$ ) in comparison to IBBS from 2007 wherein $4.8 \%$ of the population had active syphilis. ${ }^{14}$ Gonorrhea prevalence trends also indicate a decline from 35\% in 2004 to $22 \%$ in $20102010 .^{15}$

During survey findings, it is evident that 'pimps' play a far greater role in encouraging and ensuring condom use among high price FSW, and that high price 'pimps' have greater authority in promoting the 'no condom no sex' message (69.4\%). Only 54\% of low/mid-price FSW reported the same. It would beneficial to conduct qualitative study as a means to explore the reasons behind the tendency of high price 'pimps' to promote and facilitate 'no condom no sex.' For instance, as this FSW population reside with their 'pimps', are the 'pimps' more invested in the welfare of their FSW employees, as opposed to low-price who work without such supervision? Does the fact that high price can negotiate higher fees, and the numbers they serve are greater, result in greater bargaining power? Other area to explore further is the motivation behind and awareness levels of the high price male clients themselves as opposed to low-price regarding condom use.

Study into the impact of local Denpasar Government policy addressing HIV prevention and treatment would also provide insight into prevalence trends. Since 2010 the Denpasar Government has implemented and monitored a working agreement with local 'pimps', that worked around promoting four key obligations: 1) to register all of their FSWs to local government; 2) to provide education regarding STIs and HIV-AIDS to all of their FSWs; 3) to request all of their FSWs to undergo STIs regular screening; and 4) to provide condom to all of their FSWs, encouraging FSW to reject clients refusing condom use. This working agreement was legally formalized in 2013 (Peraturan Daerah Nomor 1 tentang Penanggulangan HIV-AIDS Tahun 2013). ${ }^{16}$

\section{CONCLUSION}

HIV prevalence among indirect and high-price direct FSW was much lower compared to prevalence in low/mid-price direct FSW. HIV prevalence and condom use among the entire direct FSW population are significantly associated with group price range and the role of 'pimps'.

\section{ACKNOWLEDGEMENTS}

We acknowledge the Indonesian National AIDS Commission for supporting 2007, 2009 and 2013 surveys and Dr. Wira Sunetra, Dr. Gede Agus Suryadinata, Dr. Ida Bagus Gede Ekaputra, Tri Indarti, Dr. Partha Muliawan and Dr. Pande Putu Januraga for their insightful comments and contributions to this paper.

\section{REFERENCES}

1. Wirawan DN, Fajans P, Ford K. AIDS and STDs. Risk behavior patterns among female sex workers in Bali, Indonesia. AIDS CARE 1991; 5: 289-303.

2. Ford K, Wirawan DN, Fajans P, Muliawan P, MacDonald K, Thorpe L. Behavioral interventions for reduction of sexually transmitted disease/HIV transmission among female commercial sex workers and clients in Bali, Indonesia. AIDS 1996; 10: 213-222.

3. National AIDS Commission. Republic of Indonesia Country Report on the Follow up to Declaration of Commitment on HIV/AIDS Reporting Period 2010-2011. Jakarta: 2012.

4. Direktorat Jenderal Pengendalian Penyakit dan Penyehatan Lingkungan Kementerian Kesehatan Republik Indonesia. Laporan Triwulan Situasi Perkembangan HIVఓAIDS di Indonesia Sampai Dengan 31 Maret 2010. Jakarta: 2011.

5. Direktorat Jenderal Pengendalian Penyakit dan Penyehatan Lingkungan Kementerian Kesehatan Republik Indonesia. Surveilans Terpadu Biologis dan Perilaku 2011. Jakarta: 2012. 
6. Guy M, Robert M, Agus N, Liesbeth B and Dyah EM. Is the Bed Capture Enzyme Immunoassay useful for surveillance in concentrated epidemics? The case of female sex workers in Indonesia. Southeast Asian J Trop Med Public Health 2011; 42(3): 634-642.

7. Auvert B, Taljaard D, Lagarde E, et al. Randomized, controlled intervention trial of male circumcision for reduction of HIV infection risk: the ANRS 1265 Trial. PLoS Med 2005; 2(11): e298.

8. Bailey C, Moses S, Parker CB, et al. Male circumcision for HIV prevention in young men in Kisumu, Kenya: a randomized controlled trial. Lancet 2007; 369:643-56.

9. Gray H, Kigozi G, Serwadda D, et al. Male circumcision for HIV prevention in young men in Rakai, Uganda: a randomized trial. Lancet 2007; 369:657-66.

10. Gray RH, Kiwanuka N, Quinn TC, et al. Male circumcision and HIV acquisition and transmission: cohort studies in Rakai, Uganda. AIDS 2000; 14:2371-81.

11. Weiss HA, Quigley M, Hayes R. Male circumcision and risk of HIV infection in sub-Saharan Africa: a systematic review and meta-analysis. AIDS 2000; 14:2361-70.

12. National Family Planning Coordinating Board. Indonesia Demographic Health Survey 2007. Jakarta: 2008.
13. National Family Planning Coordinating Board. Indonesia Demographic Health Survey 2012. Jakarta: 2013.

14. Direktorat Jenderal Pengendalian Penyakit dan Penyehatan Lingkungan Kementerian Kesehatan Republik Indonesia. Surveilans Terpadu Biologis dan Perilaku 2007. Jakarta: 2008.

15. Wirawan DN, Rowe E, Silfanus F, Pidari P, Satriani A and Suyetna D. Long-term trends in Neisseria gonorrhoeae and Chlamydia trachomatis prevalence among brothelbased female sex workers in Denpasar, Bali, Indonesia. Public Health and Preventive Medicine Archive 2013, 1(2):106-112.

16. Pemerintah Kota Denpasar. Peraturan Daerah Nomor 1 Tahun 2013 tentang Penanggulangan HIV dan AIDS. Denpasar: 2013.

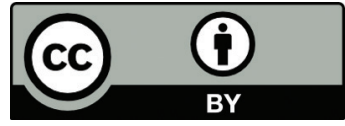

This work is licensed under a Creative Commons Attribution 